\title{
RANCANG BANGUN SISTEM INFORMASI PEKERJAAN PART TIME BERBASIS MOBILE DI WILAYAH BANDAR LAMPUNG
}

\author{
Ike Dwi Lestari' ${ }^{1)}$, S. Samsugi ${ }^{2)}$, Zaenal Abidin ${ }^{3)}$ \\ ${ }^{1}$ Sistem Informasi, Universitas Teknokrat Indonesia \\ ${ }^{2}$ Electrical Engineering, Universitas Teknokrat Indonesia \\ ${ }^{3}$ Informatika, Universitas Teknokrat Indonesia \\ Jl. H.ZA Pagaralam, No 9-11, Labuhanratu,Bandarlampung \\ Email:1ikedwi141@gmail.com, 2s.samsugi@teknokrat.ac.id, 33abin@teknokrat.ac.id
}

\begin{abstract}
Abstrak
Berdasarkan wawancara yang telah dilakukan di wilayah Bandar Lampung pada saat ini penyampaian informasi mengenai pekerjaan part time masih kurang disebabkan karena penyedia pekerjaan part time sering membagikan informasi tersebut melalui media sosial dan rekan kerja, sedangkan bagi para pekerja part time yang tidak memiliki rekan yang sering membagikan informasi pekerjaan tersebut mengalami kesulitan dalam mendapatkan informasi pekerjaan. Dari permasalahan tersebut penulis membangun sebuah sistem yang bertujuan untuk merancang Sistem Informasi Pekerjaan Part Time untuk memudahkan bagi para penyedia pekerjaan part time dalam membagikan informasi pekerjaan dan bagi para mahasiswa/i yang sedang mencari informasi pekerjaan di luar jam perkuliahan.

Penulis mengusulkan agar sistem ini dapat di gunakan untuk membantu mempermudah dalam penyajian informasi pekerjaan part time. Dalam penelitian ini penulis menggunakan metode pengembangan sistem yaitu Extreme Programming dan ISO 9126 untuk melakukan pengujian functionality dan usability pada system yang telah dibuat berdasarkan informasi dan spesifikasi.

Berdasarkan keseluruhan pengujian yang telah dilakukan mencapai 83,46\% sehingga dapat dikatakan "Baik" dan layak di gunakan, maka dapat disimpulkan bahwa Penelitian ini dapat dijadikan sebagai sarana alternatif dalam penyajian informasi pekerjaan part time wilayah Bandar Lampung.
\end{abstract}

Kata Kunci: Sistem Informasi, Pekerjaan, Part Time, Bandar Lampung, ISO 9126.

\section{Pendahuluan}

Pekerjaan adalah hal yang penting bagi setiap orang. Pekerjaan merupakan kegiatan yang dilakukan oleh setiap orang untuk mendapatkan penghasilan demi memenuhi kebutuhan hidup. Salah satu jenis pekerjaan yang dibutuhkan adalah part time, karena tidak semua orang merasa tercukupi dengan penghasilan yang didapat dari pekerjaan utamanya. Hal tersebut disebabkan oleh kebutuhan yang semakin meningkat, keperluan mendesak dan beragam alasan lainnya, dari penjelasan tersebut yang mendasari seseorang untuk mencari pekerjaan part time.

Hasil wawancara yang telah dilakukan di wilayah Bandarlampung pada toko/instansi maupun usaha perseorangan pekerjaan yang sering membutuhkan jasa part time yaitu: Penjaga Stand, Waiters, Programmer, Designr, Penyiar/ MC dan guru Private. Yang membutuhkan pekerjaan part time ini biasanya lebih banyak dari kalangan mahasiswa/i karena selain dari faktor perekonomian, pekerjaan part time ini juga mengasah ilmu dan pengetahuan. Sedangkan untuk penyedia pekerjaan part time, siapapun bisa menjadi penyedia karena tidak ada batasan khusus karena dari sisi pekerja itu sendiri yang akan memilih pekerjaan part time mana yang sesuai dengan kemampuannya. akan tetapi antara penyedia dan pencari kerja part time masih terkendala untuk penyampaian informasinya.

Pada saat ini penyampaian Informasi mengenai pekerjaan part time diwilayah bandar lampung masih kurang karena para penyedia pekerjaan part time hanya membagikan informasi tersebut melalui media sosial dan rekan kerja, disebabkan oleh belum adanya media khusus yang digunakan untuk membagikan informasi lowongan pekerjaan part time. Sedangkan bagi para pekerja part time yang tidak memiliki rekan yang sering membagikan informasi pekerjaan tersebut mengalami kesulitan dalam mendapatkan pekerjaan. biasanya para pekerja part time hanya mengetahui/melihat informasi di internet, namun informasi yang diunggah di internet terkadang tidak sesuai dengan judul artikel, seringkali judul artikel berkaitan dengan part time akan tetapi isi artikel tersebut membahas pekerjaan full time seperti artikel yang berjudul "Lowongan kerja Part time Mahasiswa lampung-Jooble ". untuk itu diperlukannya media lain yang dapat digunakan untuk menyajikan informasi pekerjaan part time.

Penelitian mengenai informasi tentang pekerjaan part-time telah di lakukan sebelumnya oleh beberapa peneliti. Penelitian tersebut antara lain Aplikasi yang dibangun yaitu pencarian lokasi tempat kerja dimana dapat menampilkan jarak lokasi pengguna ke lokasi lowongan dengan menggunakan geolokasi yang diambil menggunakan GPS service dan device 
pengguna[1]. Penelitina berikutnya yaitu membahas tentang hubungan antar kerja dan kuliah untuk mengetahui pengaruh bekerja part-time terhadap capaian pendidikan mahasiswa Fisip Unsyiah[2]. Penelitian selanjutnya ini bertujuan untuk mengetahui hubungan antara kontrol diri, beban kerja dan dukungan sosial teman sebaya terhadap prokrastinasi akademik pada mahasiswa Universitas Udayana yang bekerja part time[3]. Hasil penelitian berikutnya dapat membuktikan bahwa semakin tinggi self management yang dimiliki oleh mahasiswa maka akan diikuti penurunan stres kerja. Demikian juga sebaliknya semakin rendah self management yang dimiliki oleh mahasiswa maka stres kerja mahasiswa semakin tinggi[4]. Penelitian terakhir yaitu bahwa algoritme genetika dapat memberikan solusi yang baik untuk mengoptimasi jam kerja parttime pada cafe Bingsoo Malang [5].

\section{Metodologi}

Dalam UU No. 13 Tahun 2013 pasal 77 dan 85 disebutkan bahwa ketentuan jam kerja adalah selama 40 jam dalam satu[6]. Pekerja paruh waktu (part-time worker) adalah seseorang yang bekerja hanya dalam sebagian waktu tertentu dari kerja normal. Berdasarkan Badan Pusat Statistik yang dimaksud dengan kerja paruh waktu (part time) kerja dibawah jam normal (kurang dari 35 jam seminggu). Dengan demikian yang dimaksud kerja paruh waktu (part-time) yang dilakukan oleh mahasiswa/i dan menjadikan kerja paruh waktu tersebut sebagai pekerjaan sampingan yang dilakukan diluar kegiatan belajar pada perguruan tinggi.

\subsection{Metode Pengembangan Sistem}

Secara umum Extreme Programming (XP) dapat dijabarkan sebagai sebuah pendekatan pengembangan perangkat lunak yang mencoba meningkatkan efisiensi dan fleksibilitas dari sebuah proyek pengembangan perangkat lunak dengan mengkombinasikan berbagai ide sederhana tanpa mengurangi kualitas software yang akan dibagun [7]. Tahapan Extreme programming sebagai berikut

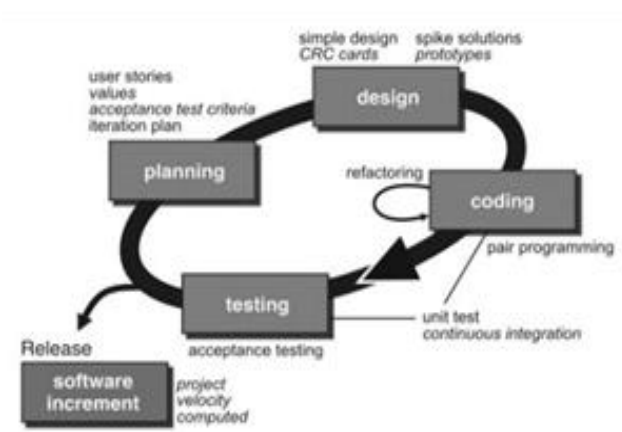

Gambar 1 Tahapan Extreme Programming

\subsection{Desain Sistem}

Desain sistem ini menggunakan UML yang merupakan tahapan yang menggambarkan secara keseluruhan bagaimana sistem tersebut akan bekerja proses pengembangan sistem[8]. Gambar 2 berikut ini menunjukkan rancangan sistem yang akan dikembangkan menggunakan use case diagram.

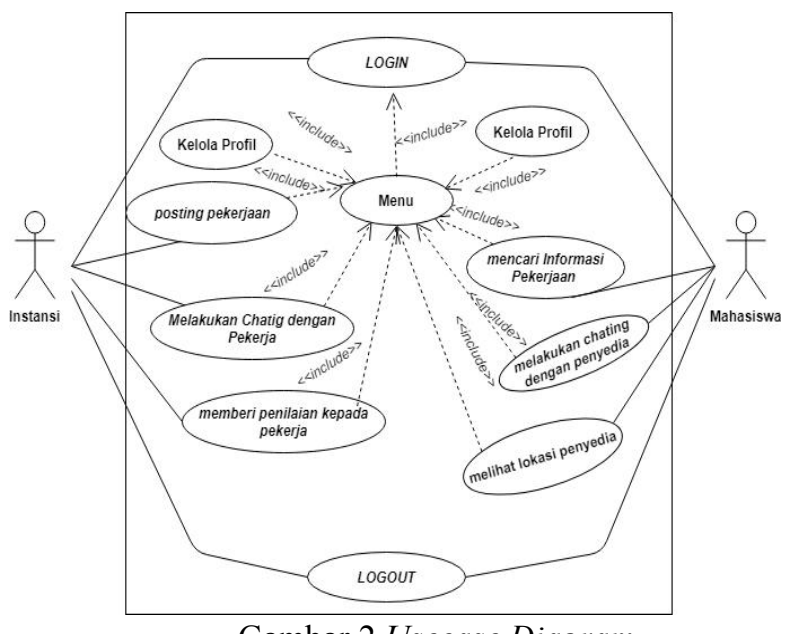

Gambar 2 Usecase Diagram

2.3. Bagan Alir yang diusulkan

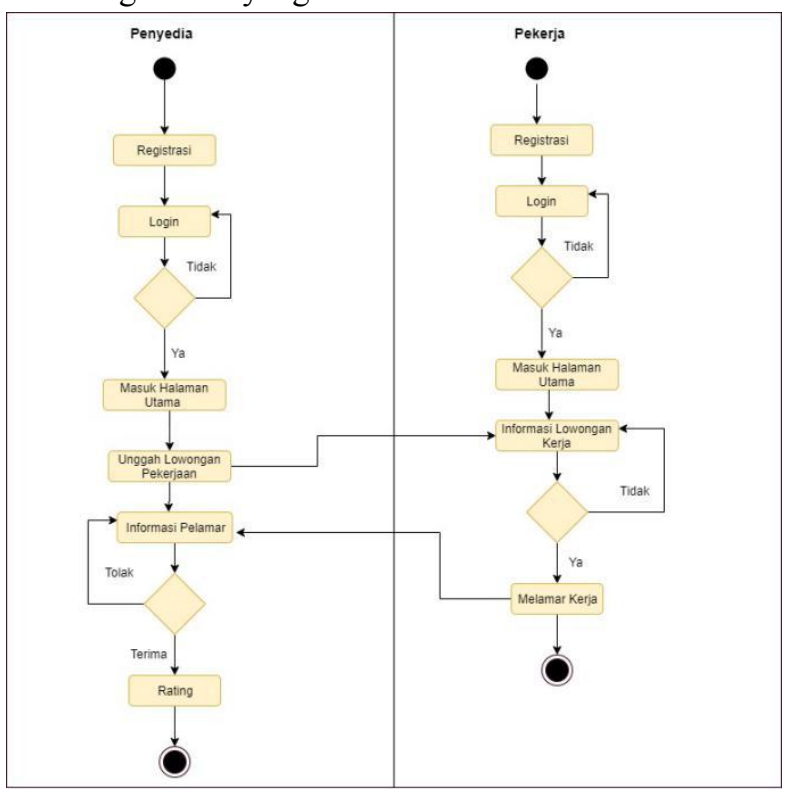

Gambar 3 Bagan Alir

Untuk dapat menggunakan aplikasi, penyedia jasa dapat melakukan Registrasi, seteh mendapat User maka dapat Login kesistem. setelah itu Penyedia dapat melakukan aktivitas untuk mengunggah Lowongan Pekerjaan. Setelah penyedia jasa mengunggah Lowongan Pekerjaan, maka Pencari kerja dapat melakukan pencarian informasi lowongan pekerjaan. setelah itu dapat memilih pekerjaan yang sesuai. 


\section{Pembahasan}

\subsection{Antarmuka Aplikasi Lowongan Pekerjaan}

Aplikasi dibangun berbasi android berupa apk, sehingga dapat di install di platform android saja[9][10]. Berikut tampilan yang telah dibuat.

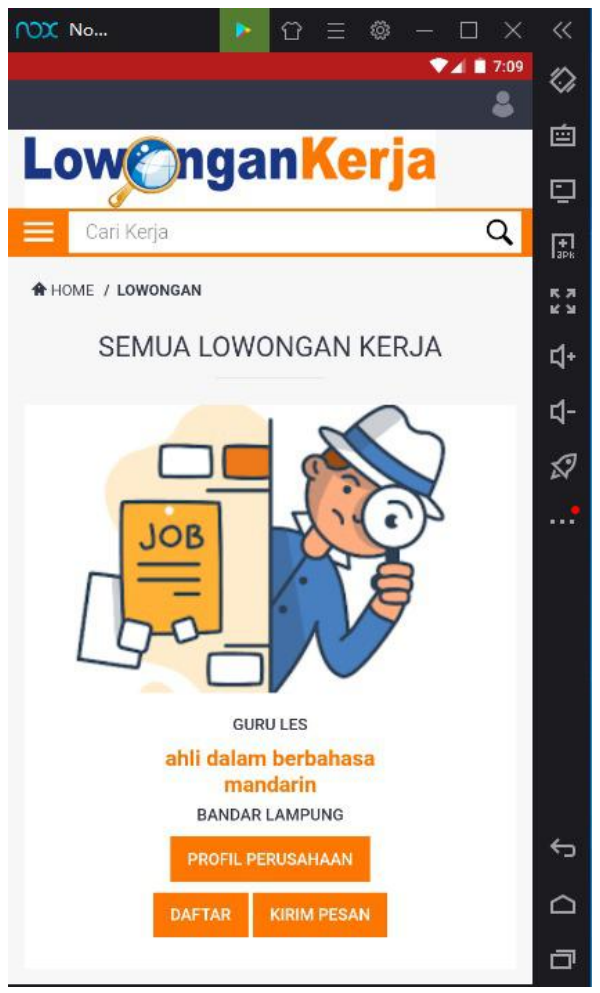

Gambar 4 Halaman Home

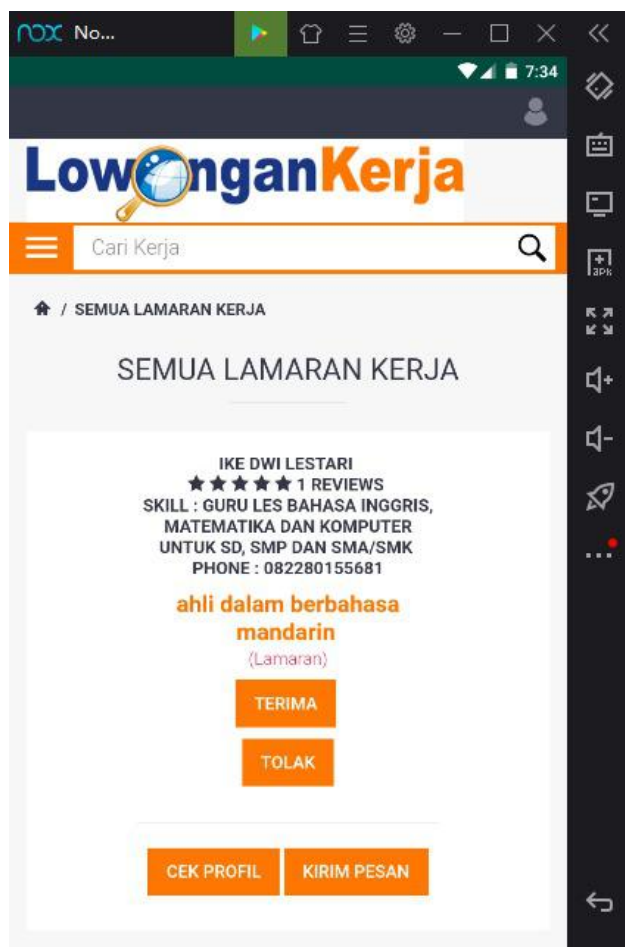

Gambar 5 Laman Informasi Lowongan

\subsection{Hasil Pengujian ISO 9126}

Berikut ini pengujian yang telah dilakukan di wilayah bandar lampung yang melibatkan 10 responden penyedia (Instansi/Usaha Perseorangan) dan 10 responden pekerja (mahasiswa/I) menggunakan skala likert dengan perincian sebagai berikut:

\begin{tabular}{|l|l|l|l|}
\hline No & Aspek & Persentase & $\begin{array}{l}\text { Tingkat } \\
\text { Kelayakan }\end{array}$ \\
\hline 1 & $\begin{array}{l}\text { Functionality } \\
\text { Penyedia }\end{array}$ & $87,5 \%$ & Layak \\
\hline 2 & $\begin{array}{l}\text { Functionality } \\
\text { Pekerja }\end{array}$ & $86,75 \%$ & Layak \\
\hline 3 & $\begin{array}{l}\text { Usability } \\
\text { Penyedia }\end{array}$ & $79,58 \%$ & Layak \\
\hline 4 & $\begin{array}{l}\text { Usability } \\
\text { Pekerja }\end{array}$ & $80 \%$ & Layak \\
\hline \multicolumn{2}{|l|}{ Total Perhitungan } & $83,46 \%$ & Layak \\
\hline
\end{tabular}

Berdasarkan hasil uji kelayakan sistem yang dibangun dengan skala llikert mencapai $83,46 \%$ dengan kesimpulan bahwa sistem informasi pekerjaan part time berbasis mobile di wilayah bandar lampung ini memiliki tingkat kelayakan yang "Baik". Sehingga dapat dikatakan bahwasanya system ini layak di gunakan.

\section{Kesimpulan}

Berdasarkan uraian tersebut dapat disimpulkan bahwa Membangun sistem informasi pekerjaan part time dengan metode Extreme Programming yang memiliki tahapan seperti: planning, Design, Coding, dan testing. Tahapan yang pertama kali dilakukan yaitu wawancara dan dokumentasi kepada penyedia (Instansi/Usaha Perseorangan) dan pekerja (Mahasiswa/i) yang berkaitan dengan pekerjaan part time. Membuat design interface untuk rancangan perangkat lunak sistem informasi pekerjaan part time. Melakukan pengkodean yang di sesuaikan dengan rancangan design interface. Tahap akhir yaitu testing kepada penyedia dan pekerja dari masing-masing pengujian terdiri dari sepuluh (10) responden pengujian yang di lakukan menggunakan ISO 9126 yang terdiri dari enam aspek yaitu: Functionality, Reability, Usability, Efesiensy, Maintability. Namun yang penulis gunakan pada sistem ini adalah Functionality dan Usability, dengan hasil perhitungan berdasarkan pengujian functionality yang telah dilakukan dari sistem informasi pekerjaan part time berbasis mobile diwilayah bandarlampung ini memperoleh hasil $87,5 \%$ diterim oleh responden Penyedia, dari responden pekerja memperoleh hasil $86,75 \%$ sedangkan pengujian menggunakan usability 
memperoleh hasil 79,58 \% di terima oleh responden penyedia dan $80 \%$ dari responden pekerja.

Sehingga hasil keseluruhan pengujian sistem informasi pekerjaan part time berbasis mobile ini mencapai $83,46 \%$ dan dapat dikatakan "Baik" dan layak digunakan, sistem ini juga dapat dijadikan sebagai sarana alternatif untuk menyajikan informasi pekerjaan part time di wilayah bandar lampung.

\section{Saran}

Berdasarkan hasil yang telah disimpulkan maka penulis menyarankan pada penelitian selanjutnya sistem dapat dikembangkan lagi, antara lain:

1. Penambahan fitur untuk wawancara online kepada pekerja yang melamar.

2. Diharapkan sistem yang akan dirancang selanjutnya bukan hanya untuk mahasiswa/i tetapi untuk semua kalangan yang membutuhkan pekerjaan part time di wilayah Bandarlampung.

\section{Daftar Pustaka}

[1] Eko, A., Putro, S., Tolle, H., \& Kharisma, A. P. (2018). Rancang Bangun Aplikasi Penawaran dan Pencarian Kerja Paruh Waktu (Part Time) Berbasis Lokasi. Jurnal Pengembangan Teknologi Informasi Dan Ilmu Komputer (JPTIIK) Universitas Brawijaya, 2(8), 2548-2964. http://j-ptiik.ub.ac.id

[2] Fitria, \& Drs. Zulfan, M. H. (2013). Hubungan Kerja Part Time Dengan Capaian Pendidikan Mahasiswa. 3(2), 273-282.

[3] Gede, I. D., \& Dinata, A. (2019). Hubungan kontrol diri, beban kerja dan dukungan sosial teman sebaya terhadap prokrastinasi akademik pada mahasiswa Universitas Udayana yang bekerja part time. Psikologi, 6(1), 103-115.

[4] Rayi Hemas Citra Pertiwi. (2018). Self Management Dengan Stres Kerja Pada Mahasiswa Pekerja Sistem Part-Time Jurusan Administrasi Bisnis Politeknik Negeri Semarang. Jurnal Empati, 7(Nomor 4), 191-198.

[5] Suwandy, Y., \& Muflikhah, L. (2019). Penerapan Algoritme Genetika untuk Optimasi Penjadwalan Jam Kerja Part-Time Studi Kasus Cafe Bingsoo Malang. Jurnal Pengembangan Teknologi Informasi Dan Ilmu Komputer (J-PTIIK) Universitas Brawijaya, 3(1), 836-841.

[6] Ketenagakerjaan, Pub. L. No. No. 13, pasal 77 dan 85 (2013).

[7] Keina. (2013). Metodologi Extreme Programming - Keina Tralala. https://keinatralala.com/2013/12/13/metodologiextreme-programming/

[8] Sukamto, R., \& M. Shalahuddin. (2018). Rekayasa Perangkat Lunak Terstruktur dan Berorientasi Objek. Informatika.

[9] Firly, N. (2018). Create Your Own Android Application. Pt Elex Media Komputindo Kompas Gramedia Building.

[10] M. Nurhidayat. (2017). Jurus Rahasia Menguasai Pemrograman Android. PT Elex Media Komputindo Kompas Gramedia Building. 